\title{
PERAMALAN JUMLAH PENDERITA DEMAM BERDARAH DENGUE DI KOTA DENPASAR MENGGUNAKAN MODEL FUNGSI TRANSFER MULTIVARIAT
}

\author{
Novian Endi Gunawan ${ }^{1}$, I Wayan Sumarjaya ${ }^{2}$, I G.A.M. Srinadi ${ }^{3}$ \\ ${ }^{1}$ Program Studi Matematika, FMIPA - Universitas Udayana [Email: vianendi@ gmail.com] \\ ${ }^{2}$ Program Studi Matematika, FMIPA - Universitas Udayana [Email: sumarjaya@ unud.ac.id] \\ ${ }^{3}$ Program Studi Matematika, FMIPA - Universitas Udayana [Email: srinadi@unud.ac.id] \\ ${ }^{\S}$ Corresponding Author
}

\begin{abstract}
Forecasting is a way to predict future events. One model in forecasting is a transfer function. The transfer function is a forecasting model that combines characteristics of the ARIMA model with some characteristics of regression analysis. Dengue Hemorrhagic Fever is a major problem in Bali. Recorded Bali Province ranked fourth in the spread of dengue virus and Denpasar City ranked first in the number of death cases of Dengue Hemorrhagic Fever. The purpose of this research is to know the multivariate transfer function model and the prediction of people with Dengue Hemorrhagic Fever in Denpasar City based on the level of rain and humidity. Forecasting results in 2017 in January to June were 46, 51, 226, 625, 1064, 1001, and 580 peoples with a percentage error model transfer function of $17.2 \%$.
\end{abstract}

Keywords: Dengue Hemorrhagic Fever, SARIMA, Transfer Function Multivariate.

\section{PENDAHULUAN}

Meramal adalah suatu cara untuk memperkirakan kejadian pada masa yang akan datang. Membuat sebuah prediksi atau ramalan disebut sebagai peramalan (Bowerman et al, 2005). Peramalan tidak selalu tepat $100 \%$ karena pada masa depan akan terdapat banyak faktor yang memengaruhi proses peramalan. Peramalan biasanya melibatkan analisis deret waktu, di mana analisis deret waktu didasarkan pada data kuantitatif masa lalu dan hasil ramalannya bergantung pada metode yang digunakan.

Model ARIMA merupakan gabungan dari metode dekomposisi, metode penghalusan, dan metode regresi deret waktu, namun model ARIMA merupakan model untuk meramalkan satu variabel (univariat) (Wei, 2006). Untuk peramalan dengan banyak variabel (multivariat) terdapat beberapa model yang dapat digunakan yaitu model fungsi transfer. Model fungsi transfer atau sering disebut multivariat autoregressive integrated moving average merupakan model peramalan yang menggabungkan beberapa karakteristik model ARIMA dengan beberapa karakteristik analisis regresi (Makridakis, et al., 1999). Peramalan merupakan salah satu solusi dalam perencanaan di segala aspek kehidupan tidak terkecuali dalam aspek kesehatan. Indonesia sebagai salah satu negara dengan daerah beriklim tropis rentan akan timbulnya berbagai penyakit tropis yang disebabkan oleh nyamuk dan sering berjangkit di masyarakat seperti Demam Berdarah Dengue dan malaria (Kementrian Kesehatan RI, 2016).

Provinsi Bali menempati peringkat keempat dalam penyebaran virus Dengue di Indonesia. Kota Denpasar dan Kabupaten Gianyar menjadi daerah yang potensial penyebaran virus Dengue. Kabupaten Gianyar menempati peringkat pertama dalam jumlah kasus Demam Berdarah Dengue sedangkan Kota Denpasar menempati peringkat pertama dalam jumlah kematian pada kasus Demam 
Berdarah Dengue (Depkes Provinsi Bali, 2016). Adapun tujuan dari penelitian ini adalah untuk mengetahui model fungsi transfer multivariat dari jumlah penderita Demam Berdarah Dengue di Kota Denpasar dan untuk mengetahui hasil peramalan jumlah penderita Demam Berdarah Dengue di Kota Denpasar pada tahun 2017.

\section{METODE PENELITIAN}

Data pada penelitian ini adalah data sekunder, yaitu data bulanan penderita penyakit Demam Berdarah Dengue di Kota Denpasar, yang diperoleh melalui Dinas Kesehatan Kota Denpasar. Data bulanan curah hujan dan kelembaban di Kota Denpasar, yang diperoleh melalui Badan Pusat Statistik Provinsi Bali. Data yang digunakan dari tahun 2010 sampari 2016, dimana data in-sample mulai Januari 2010 sampai Juni 2016 sebanyak 78 data dan data out-sample mulai Juli 2016 sampai Desember 2016 sebanyak 6 data. Variabel tak bebas dalam penelitian ini adalah jumlah penderita Demam Berdarah Dengue di Kota Denpasar. Variabel bebas dalam penelitian ini adalah curah hujan dan kelembaban udara di Kota Denpasar.

Langkah-langkah yang dilakukan pada penelitian ini sebagai berikut:

1. Mengidentifikasi plot deret waktu, ACF, dan PACF data deret input (variabel bebas) dan deret output (variabel takbebas) untuk mengetahui kestasioneran data;

2. Menentukan model ARIMA untuk deret input dengan melihat plot ACF dan PACF;

3. Menghitung estimasi parameter model ARIMA untuk masing-masing input;

4. Melakukan uji diagnosik model ARIMA dengan memenuhi asumsi white noise dan kenormalan;

5. Pemilihan model terbaik berdasarkan nilai AIC;

6. Melakukan prewhitening pada deret input untuk memperoleh $\alpha_{t}$

7. Melakukan prewhitening pada deret output untuk memperoleh $\beta_{t}$
8. Menghitung korelasi silang antara deret input dan output yang telah di prewhitening;

9. Mengestimasi nilai bobot impuls fungsi transfer tunggal;

10. Menetapkan nilai $(b, s, r)$ untuk menduga model fungsi transfer tunggal;

11. Identifikasi deret noise;

12. Menetapkan $\left(p_{n}, q_{n}\right)$ untuk model ARIMA dari deret noise $N_{t}$;

13. Mengestimasi parameter model fungsi transfer tunggal;

14. Uji diagnosis model fungsi transfer tunggal;

15. Pemilihan model terbaik fungsi transfer tunggal;

16. Identifikasi deret noise gabungan ;

17. Menetapkan $\left(p_{n}, q_{n}\right)$ untuk model ARIMA $\left(p_{n}, 0, q_{n}\right)$ dari deret noise gabungan $N_{t}$;

18. Mengestimasi parameter model fungsi transfer multivariat;

19. Uji diagnosik model fungsi transfer multivariat;

20. Pemilihan model terbaik fungsi transfer multivariat;

21. Meramalkan jumlah penderita Demam Berdarah Dengue di Kota Denpasar tahun 2017.

\section{HASIL DAN PEMBAHASAN}

\subsection{Identifikasi Data Deret Waktu}

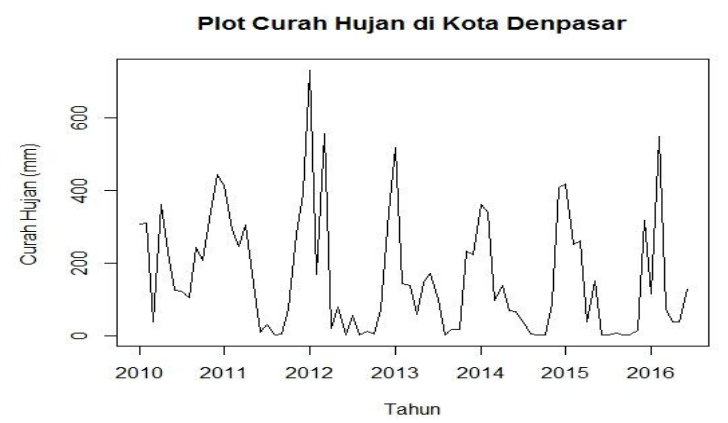

Gambar 1. Plot Data Curah Hujan Bulan Januari 2010 - Juni 2016. 


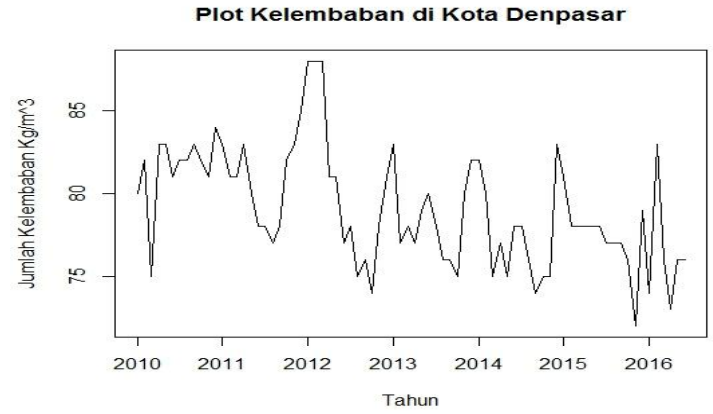

Gambar 2. Plot data kelembaban bulan Januari 2010 - Juni 2016.

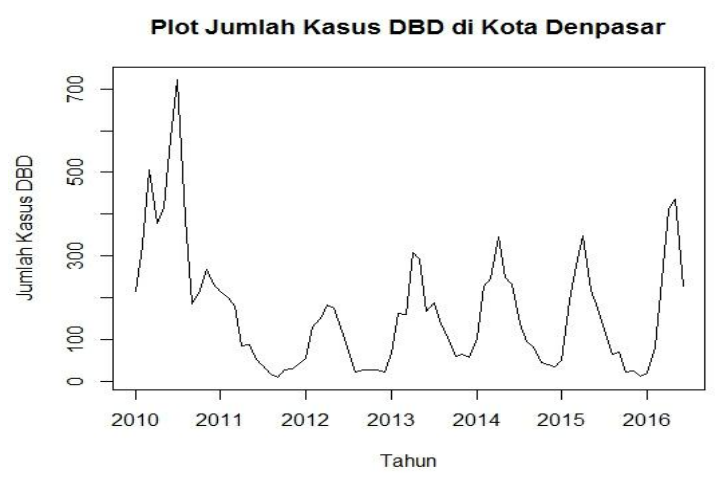

Gambar 3. Plot data jumlah kasus DBD bulan Januari 2010 - Juni 2016.

Gambar 1 - 3 memperlihatkan bahwa data curah hujan, kelembaban dan jumlah kasus demam berdarah di Kota Denpasar berfluktuasi. Ada dugaan data berpola tren dan musiman, untuk mengetahui secara pasti pola tren dan musiman bahwa pada data maka dilakukan metode dekomposisi klasik.

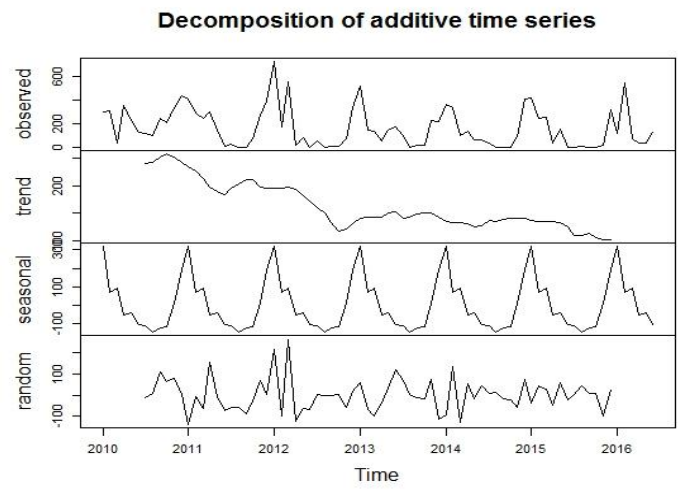

Gambar 4. Plot Dekomposisi Klasik Curah Hujan Bulan Januari 2010 - Juni 2016.
Dekomposisi Klasik Kelembaban

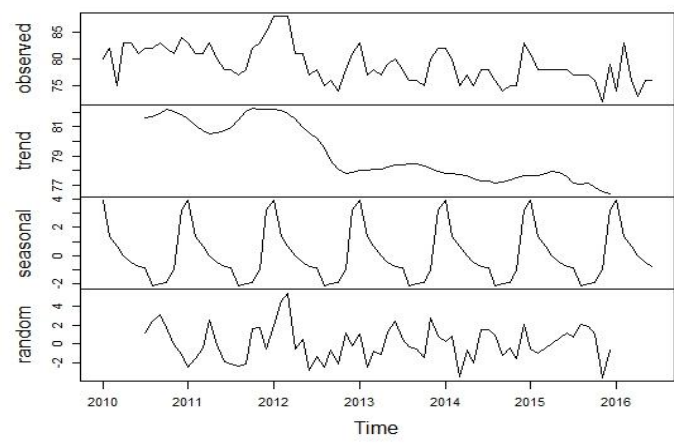

Gambar 5. Plot Dekomposisi Klasik Kelembaban Bulan Januari 2010 - Juni 2016.

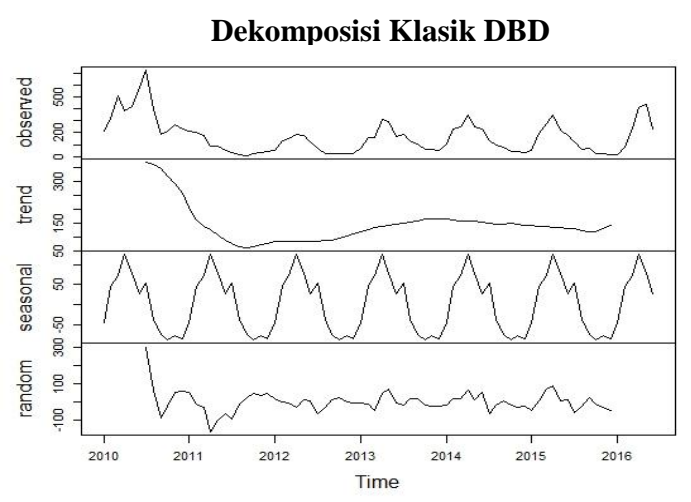

Gambar 6. Plot Dekomposisi Klasik Kasus DBD Bulan Januari 2010 - Juni 2016.

Gambar 4- 6 merupakan plot dekomposisi deret waktu curah hujan, kelembaban, dan jumlah kasus DBD di Kota Denpasar yang menunjukkan bahwa terdapat pengaruh tren yang cenderung menurun serta pengaruh musiman pada data, sebab memiliki pola yang berulang secara teratur. Adanya pengaruh tren dan musiman menjelaskan bahwa data deret waktu curah hujan, kelembaban, dan jumlah kasus DBD di Kota Denpasar tidak stasioner, selanjutnya dilakukan differencing agar data stasioner. 


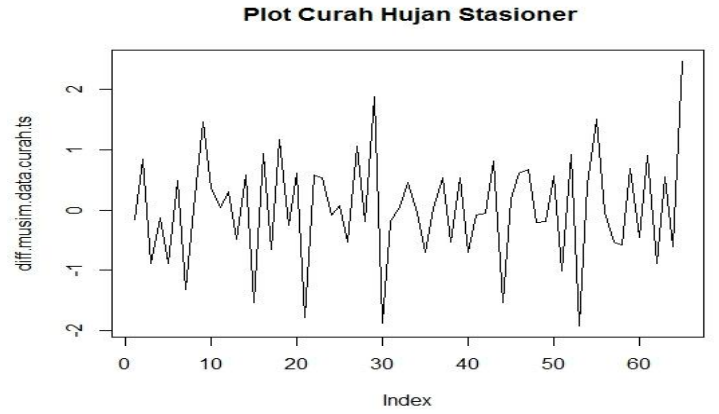

Gambar 7. Plot Deret Waktu Curah Hujan Setelah Transformasi Log dan differencing

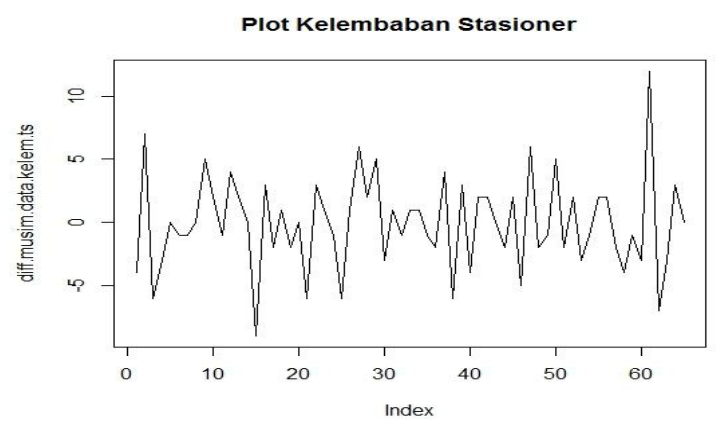

Gambar 8. Plot Deret Waktu Kelembaban Transformasi Log dan Differencing

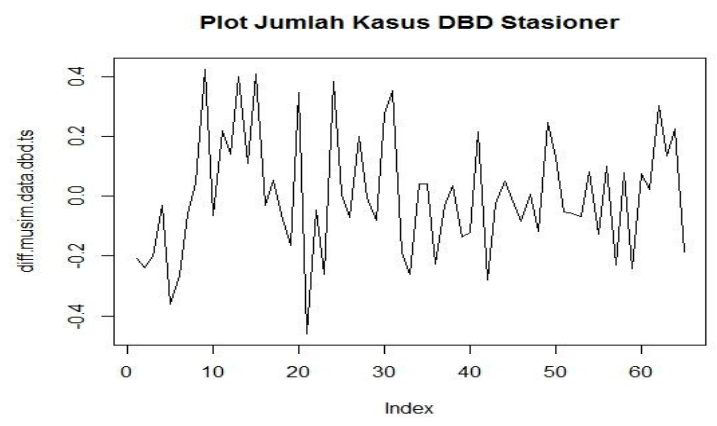

Gambar 9. Plot Deret Waktu Jumlah Kasus DBD Setelah Transformasi $\log$ dan Differencing

Gambar 7-9 menunjukkan data curah hujan, kelembaban dan jumlah kasus DBD di Kota Denpasar yang telah stasioner.

\subsection{Penentuan Model ARIMA Curah Hujan}

Penentuan model ARIMA curah hujan dapat dilihat pada Plot ACF dan PACF berikut:

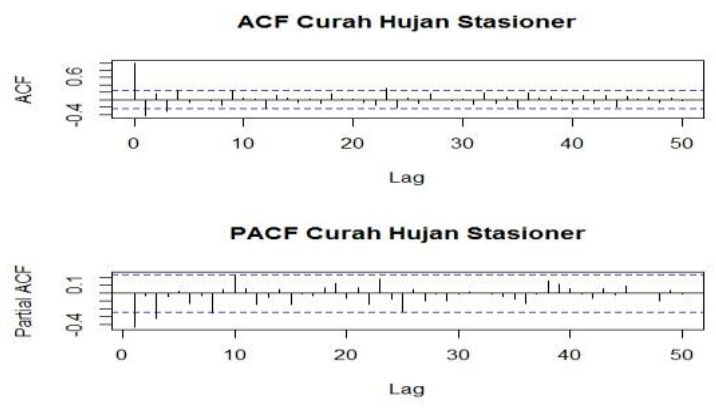

Gambar 10. Plot ACF dan PACF Data Curah Hujan yang Telah didifferencing

Gambar 10 menunjukkan plot ACF signifikan pada lag 1,3 dan 12 yang menyatakan bahwa komponen nonmusiman akan digunakan MA orde 1 dan 3, sedangkan komponen musiman akan digunakan SMA orde 1 dan 3. Pada plot PACF terpotong pada lag 1 dan 3 yang menjelaskan bahwa komponen nonmusiman akan digunakan AR orde 1 dan 3. Kombinasi orde-orde yang diperoleh ditatapkan dalam model $\operatorname{AR}(1)$, AR(3), MA(1), MA(3), SMA(1) dan SMA(3). Model ARIMA multiplikatif yang akan diuji adalah model SARIMA $(1,1,0)(0,1,1)^{12}$, $\operatorname{SARIMA}(3,1,0)(0,1,1)^{12}$, SARIMA $(0,1,1)(0,1,1)^{12}$ SARIMA $(0,1,3)(0,1,1)^{12}$,SARIMA $(1,1,0)(0,1,3)^{12}$ dan $\operatorname{SARIMA}(0,1,1)(0,1,3)^{12}$.

\subsection{Penentuan Model ARIMA Kelembaban}

Penentuan model ARIMA kelembaban dilihat pada Plot ACF dan PACF berikut:

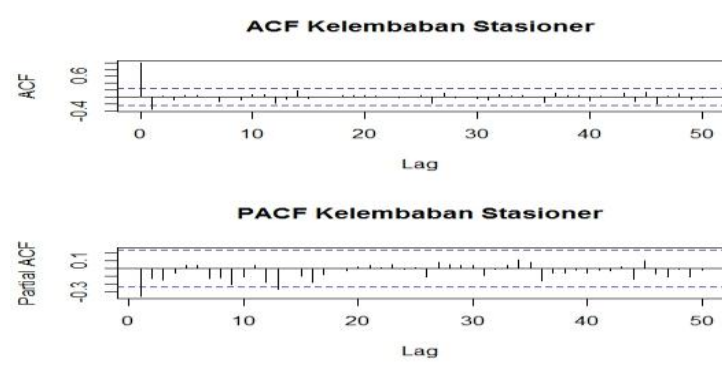

Gambar 11. Plot ACF dan PACF Data Kelembaban Yang Telah didifferencing

Gambar 11 merupakan plot ACF dan PACF data kelembaban yang telah didifferencing terhadap trend dan musiman. 
Dapat dilihat bahwa plot ACF terpotong pada lag 1 menyatakan bahwa komponen nonmusiman akan digunakan MA orde1. Pada plot PACF terpotong pada lag 1 yang berarti tidak terdapat komponen musiman dan untuk komponen nonmusiman digunakan AR orde 1 . Model ARIMA yang diuji adalah model, ARIMA $(1,1,0)$, ARIMA $(0,1,1)$ dan ARIMA $(1,1,1)$.

\subsection{Penentuan Model Terbaik}

Dari beberapa model ARIMA curah hujan dan kelembaban yang telah memenuhi asumsi whine noise kenormalan residual, selanjutnya akan dilakukan pemilihan model terbaik berdasarkan nilai AIC terkecil. Variabel curah hujan dapat ditentukan model terbaiknya yaitu, $\operatorname{SARIMA}(0,1,1)(0,1,1)^{12}$ dengan nilai AIC 37,855. Model terbaik dari variabel kelembaban yaitu, ARIMA $(1,1,1)$ dengan nilai AIC -418,5525. Model ARIMA yang di coba untuk masing-masing variabel dapat dilihat pada Lampiran 1.

\subsection{Identifikasi Model Fungsi Transfer \\ a. Prewhitening Deret Input}

Prewhitening deret input curah hujan dengan model SARIMA $(0,1,1)(0,1,1)^{12}$ adalah

$$
\begin{aligned}
& \alpha_{t}^{1}= \\
& \left(x_{t}^{1 *}\right)-0,6055 \alpha_{t-1}^{1}+0,3627 \alpha_{t-12}^{1}+ \\
& 0,2196 \alpha_{t-13}^{1} .
\end{aligned}
$$

Prewhitening deret input kelembaban dengan model ARIMA $(1,1,1)$ adalah

$$
\frac{\left(1-0,9999 \alpha_{t-1}^{2}\right)}{\left(1-0,5191 \alpha_{t-1}^{2}\right)}\left(x_{t}^{2 *}\right)=\alpha_{t}^{2} \text {. }
$$

\section{b. Prewhitening Deret Output}

Prewhitening deret output terhadap curah hujan $\left(Y_{t}^{*}\right)$ dengan model SARIMA $(0,1,1)(0,1,1)$ adalah:

$$
\begin{aligned}
& \beta_{t}^{1}=\left(y_{t}^{*}\right)-0,6055 \beta_{t-1}^{1}+0,3627 \beta_{t-12}^{1}+ \\
& 0,2196 \beta_{t-13}^{1}
\end{aligned}
$$

Prewhitening deret output terhadap kelembaban $\left(Y_{t}^{*}\right)$ dengan model ARIMA $(1,1,1)$ adalah:

$$
\frac{\left(1-0,9999 \beta_{t-1}^{2}\right)}{\left(1-0,5191 \beta_{t-1}^{2}\right)}\left(y_{t}^{*}\right)=\beta_{t}^{2}
$$

\section{Penghitungan Korelasi Silang Deret Input dan Output yang telah di Prewhitening}

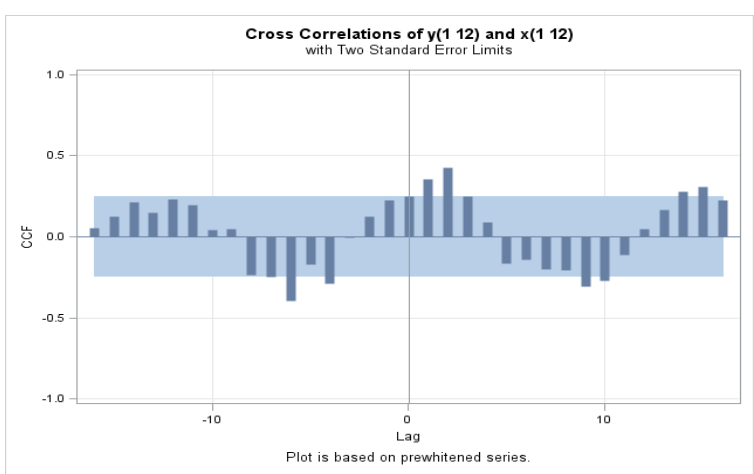

Gambar 12. Plot korelasi Silang antara Deret Input Curah Hujan dengan Deret Output Jumlah Kasus DBD

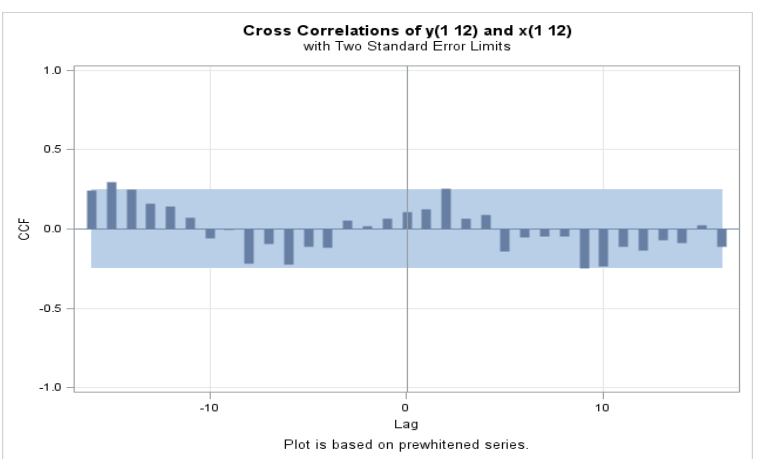

Gambar 13. Plot korelasi Silang antara Deret Input Kelembaban dengan Deret Output jumlah Kasus DBD

Pada variabel curah hujan yang telah ditransformasi Gambar 12 terlihat lag yang pertama kali memengaruhi secara signifikan adalah lag 1, menunjukkan bahwa variabel output dipengaruhi oleh input curah hujan sampai periode $t+1$. Nilai $r$ adalah 2 dikarenakan pada plot korelasi silang terlihat mengikuti pola sinus yang menunjukkan $y_{t}$ dipengaruhi oleh $y_{t-1}$ dan $y_{t-2}$ sedangkan nilai $s$ adalah 1 yang menunjukkan $y_{t}$ secara terus menerus dipengaruhi oleh $x_{t-b-1}$.

Pada variabel kelembaban yang telah ditransformasi Gambar 13 nilai $r$ dan $s$ adalah nol karena tidak terdapat pola yang jelas pada plot korelasi silang dan untuk nilai $b$ adalah 2 karena lag yang pertama kali memengaruhi secara signifikan yang menjelaskan variabel output tidak dipengaruhi oleh input kelembaban sampai periode $t+2$ atau dipengaruhi pada dua bulan sebelumnya. 
Model fungsi transfer curah hujan

$y_{t}=\frac{\omega_{0}-\omega_{1} B}{\left(1-\delta_{1} B-\delta_{2} B^{2}\right)} x_{t-1}^{1}+n_{t}$.

Model fungsi transfer kelembaban

$y_{t}=\omega_{0} x_{t-2}^{2}+n_{t}$.

\subsection{Menetapkan Model ARIMA dari Deret Noise}
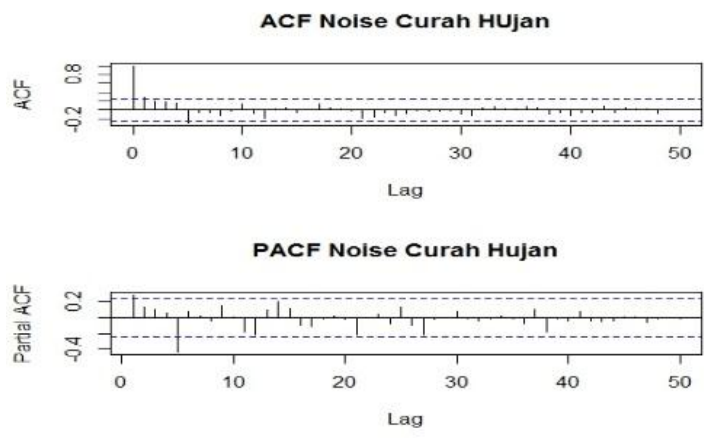

Gambar 14. Plot ACF dan PACF Deret Noise Curah Hujan
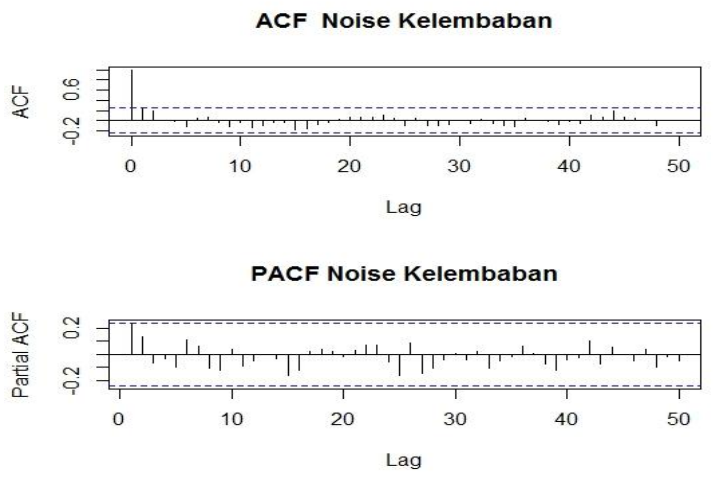

Gambar 15. Plot ACF dan PACF Deret Noise Kelembaban

Gambar 14 dan 15 pada plot ACF dari deret noise terlihat tidak ada pengaruh pola musiman. Dari plot ACF dan PACF deret noise curah hujan diperoleh model ARMA $(1,0,0)$, ARMA $(0,0,1)$ dan ARMA $(1,0,1)$. Untuk deret noise kelembaban pada plot ACF dan PACF diperoleh model ARIMA $(1,0,0)$, ARMA $(0,0,1)$ dan ARMA $(1,0,1)$.

\section{Pemilihan Model Terbaik Fungsi Transfer}

Pemilihan model terbaik dilakukan setelah model telah memenuhi uji diagnostik model. Model terbaik fungsi transfer untuk variabel curah hujan adalah $y_{t}=\frac{0,0837+0,1190 B}{\left(1+0,0817 B-0,4949 B^{2}\right)} x_{t-1}^{1}+\frac{1}{(1+0,0790 B)} a_{t}$

dengan nilai AIC -24,7606.

Model terbaik fungsi transfer untuk variabel kelembaban adalah

$y_{t}=3,1523 x_{t-2}^{2}+\frac{1}{(1+0,1007 B)} a_{t}$,

dengan nilai AIC -27,8119.

\section{Model Fungsi Transfer Multivariat}

Setelah diperoleh model fungsi transfer pada masing-masing variabel selanjutnya dilakukan pemodelan fungsi transfer multivariat.

$y_{t}=\frac{\omega_{0}-\omega_{1} B}{\left(1-\delta_{1} B-\delta_{2} B^{2}\right)} x_{t-1}^{1}+\omega_{0} x_{t-2}^{2}+$ noise,

Selanjutnya model ARIMA deret noise gabungan dapat dilihat dari plot ACF dan PACF nya didapatkan model noise yang akan dicoba adalah ARMA $(0,0,1), \operatorname{ARMA}(1,0,0)$ dan ARMA $(1,0,1)$. Model noise gabungan yang didapat, disubstitusikan kedalam model fungsi transfer multivariat.

Model fungsi transfer multivariate terbaik adalah

$y_{t}=\frac{0,0792+0,0931 B}{\left(1+0,1397 B-0,5275 B^{2}\right)} x_{t-1}^{1}+$

$1,9396 x_{t-2}^{2}+\frac{1}{(1+0,1068 B)} a_{t}$,

Persamaan (1) adalah model terbaik fungsi transfer multivariat dengan nilai AIC -24,411. Model tersebut menunjukkan bahwa jumlah kasus DBD di Kota Denpasar dipengaruhi curah hujan satu bulan sebelumnya dan kelembaban dua bulan sebelumnya. Model fungsi transfer multivariat selengkapnya dapat dilihat pada Lampiran 2.

\subsection{Peramalan Kasus Demam Berdarah Dengue di Kota Denpasar}

Hasil ramalan dari Persamaan (1) diperoleh MAPE in-sample sebesar 7\% dan MAPE out-sample sebesar $17,2 \%$ hal tersebut menunjukkan persentase dalam meramalkan jumlah kasus demam berdarah dengue di Kota Denpasar. Hasil ramalan yang telah ditransformasi kembali dan dibulatkan dari jumlah demam berdarah dengue di Kota 
Denpasar dengan model fungsi transfer multifavariat pada bulan Januari 2017 sampai Juni 2017 dapat dilihat pada Tabel 1.

Tabel 1 . Hasil Peramalan Jumlah Demam Berdarah Dengue di Kota Denpasar.

\begin{tabular}{|l|r|}
\hline Bulan & Ramalan \\
\hline Januari & 51 \\
\hline Februari & 226 \\
\hline Maret & 625 \\
\hline April & 1064 \\
\hline Mei & 1001 \\
\hline Juni & 580 \\
\hline
\end{tabular}

\section{SIMPULAN DAN SARAN}

\subsection{Simpulan}

Berdasarkan hasil dan pembahasan, dapat simpulkan sebagai berikut:

1. Model fungsi transfer multivariat untuk peramalan jumlah penderita demam berdarah dengue di Kota Denpasar adalah:

$y_{t}=\frac{0,0792+0,0931 B}{\left(1+0,1397 B-0,5275 B^{2}\right)} x_{t-1}^{1}+$ $1,9396 x_{t-2}^{2}+\frac{1}{(1+0,1068 B)} a_{t}$

2. Hasil ramalan jumlah penderita demam berdarah dengue di Kota Denpasar dari Januari 2017 sampai Juni 2017 adalah 51, $226,625,1064,1001$, dan 580 orang.

\subsection{Saran}

Untuk penelitian selanjutnya dapat mempertimbangkan faktor lain ataupun dapat membandingkan dengan metode multivariat lainnya.

\section{UCAPAN TERIMA KASIH}

Ucapan terima kasih disampaikan kepada I Putu Eka Nila Kencana, Made Susilawati, dan Kartika Sari di Program Studi Matematika yang memberikan masukan berharga untuk penyempurnaan tulisan ini.

\section{Daftar Pustaka}

Bowerman, Richard, T., Bruce, L., O'Connell., and Koehler, A.B., 2005. Forecasting, Time Series, And Regression: An Applied Approach. 4th ed. Boston: Brooks/Cole.

Box, G. E., Jenkins, G. M., Reinsel, G. C. \& Ljung, G. M., 2016. Time Series Analysis: Forecasting and Control. Fifth ed. San Fransisco: John Wiley and Sons.

Depkes Provinsi Bali, 2016. Profil Kesehatan Provinsi Bali 2015. Denpasar: Depkes Provinsi Bali.

Kementrian Kesehatan RI, 2016. Wilayah KLB DBD Ada di 11 Provinsi. [Online] Available at: http://www.depkes.go.id/article/print/1603 0700001/wilayah-klb-dbd-ada-di-11provinsi.html

[Accessed 12 March 2017].

Makridakis, S., Wheelwright, S. C. \& McGee, V. E., 1999. Metode dan Aplikasi Peramalan Jilid 1. Edisi Kedua . Jakarta: Erlangga.

Wei, W. W., 2006. Time Series Analysis: Univariate and Multivariate Methods. Second ed. New York: Pearson Addison Wesley. 